two cranks at $180^{\circ}$ apart and these drive two heavy 'planets', which have a slight freedom of movement in a radial direction relative to the crank pins. When the shaft is revolved at high speed, the planets are thrown outwards by centrifugal force and their outer surfaces come into contact with the inner surface of a fixed annular casing around which they begin to roll. The disc of each planet is pierced with circular holes and in these fit loosely a corresponding number of rollers and studs carried by discs on the driven shaft. It is through these that the power is transmitted. The gear can be arranged so that if necessary the second shaft is fixed while the casing revolves, while by using planets of a different design the gear can be made reversible. The exhibit attracted considerable attention and it is to be hoped will soon be tried on a large scale.

\section{A Dinosaur from Montana}

During the past summer, a party from the American Museum of Natural History, under the leadership of Mr. Barnum Brown, has explored the Cretaceous rocks of Montana in which remains of fossil reptiles occur. According to a message from the New York correspondent of the Times which appears in the issue of Oct. 1, it has found a nearly complete skeleton of the armadillo-shaped dinosaur Nodosaurus, which has hitherto been known only from fragments. The reptile is remarkably broad, for although it is only $14 \mathrm{ft}$. long, it is $7 \mathrm{ft}$. wide at the hips. It is heavily armoured with bony plates, which are arranged to give flexibility to the trunk and tail. It has feeble teeth adapted for feeding on either vegetables or insects. Nodosaurus was first recognised and named in 1889 by the late Prof. O. C. Marsh, who received characteristic pieces of it from his collectors in the Cretaceous rocks of Wyoming. A somewhat similar fossil skeleton, without head, was discovered in 1913 by the late Mr. W. E. Cutler in corresponding deposits in Alberta, Canada, and it is now exhibited in the British Museum (Natural History). It was named Scolosaurus cutleri by Baron Nopcsa, who published a restored drawing of it by Miss Alice B. Woodward in the Illustrated London News of Sept. 11, 1926. Scolosaurus must have been about $12 \mathrm{ft}$. long, and would be only about $3 \mathrm{ft}$. high when walking. A smaller reptile of the same group was found long ago by the late Rev. William Fox in the Wealden formation in the cliffs on the south coast of the Isle of Wight, but he was able to recover it only in a rather fragmentary state. It was named Polacanthus foxi by Hulke, and is now also exhibited in the British Museum (Natural History).

\section{Memorial to the Late Sir Andrew Balfour}

ON October 6 the Earl of Athlone, Chancellor of the University of London, unveiled a memorial tablet to the late Sir Andrew Balfour, first director of the London School of Hygiene and Tropical Medicine, in the entrance hall of the School. The tablet, which is of polished Roman stone with a bas-relief head in bronze, is the visible part of a twofold memorial, the other purpose being a scheme to enable students, preferably those from overseas, to pursue courses of study at the School. At the ceremony the Chancellor paid a well-deserved tribute to Sir Andrew and his world-wide work in the cause of tropical medicine and public health. Referring to the organisation of the London School of Hygiene and Tropical Medicine he said : "To that work which was, alas, to prove the last of his labours - the building, the equipment, the organisation of this great School-Andrew Balfour brought the same passionate zeal, the same untiring energy which were characteristic of his whole career, and his inspiring personality is so very fresh in the minds of all of you that of his last great piece of work there is hardly any need to speak. The appointment of Andrew Balfour to be the first Director of this School gave to the School from its very inception a splendid introduction throughout the whole world and contributed perhaps more than anything else to the reputation which it has already established. Finally, and in a word, Balfour was a great Empire builder; and when I say this I am thinking not so much of his devotion to work, of his vast knowledge and contributions to the subject of Empire health, not of his academic distinctions, not of his contributions to sport and literature, but of his fine character. He was without guile, honest to the core, a man who evoked in his colleagues a spirit of love and sacrifice." It is fitting that the memorial tablet bears the quotation from Walt Whitman which Balfour himself loved :

"Through the battle, through defeat, moving yet and never stopping,

Pioneers! O pioneers !"

\section{Excavations in Westmeath, Ireland}

ExcEPtional interest is attached to the finds which have been made by the Harvard University Archæological Expedition in excavating a crannog at Ballinderry, near Moate, Co. Westmeath, Ireland, and an early bronze age cairn at Knockast nearby. The excavations are in charge of Dr. H. O'Neill Hencken, whose recent book on Cornwall in the "County Archæologies" series, has given him an assured place among authorities on British archæology. The crannog was first identified by Dr. Adolf Mahr, of the National Museum of Ireland, some four years ago, when a Viking sword was found in the course of cutting a drain across the bog. The island constituting the crannog is built up of layers of brushwood and peat contained by timber piles, on which lay a substructure of massive timbers supporting further layers of peat and brushwood and the floor of a circular dwelling. Above this, and built some time later, were two smaller rectangular houses. Judging from the animal remains, the inhabitants were both hunters and herdsmen, while the coulter of a plough and querns indicate their practice of agriculture. In place of pottery they used well-turned wooden vessels, made on a lathe, and barrels made of staves and hoops. Among the tools and weapons of iron was a Viking battle-axe. The remains are dated at about A.D. 1000. The

No. 3285 , VoL. 130] 
most remarkable finds were a hanging lamp and a gaming board. The former is describod by a correspondent of the Times, who gives an account of the discovery in the issue of Oct. 7, as "the finest bronze which has yet come to light in excavation in Ireland". It is a pointed oval, with threo hanging chains attached to animal heads, and is decorated with rosettes and an acanthus scroll. It will be interesting to hear Mr. Kendrick's analysis of its relation to the British hanging bowls, from which descent is claimed for it. The wooden gaming board has forty-nine holes and is bordered with carved Celtic patterns, said to be the finest Viking object known from Ireland.

\section{Television Broadcasting}

THE transmissions from Broadcasting House, London, of television by the Baird process have fulfilled the expectations of the radio engineers. Some think that this may load to the revival of the 'puppet' show which was very popular about two hundred years ago. The London transmissions have been seen well in Scotland, a distance of more than 400 miles. At prosent two bands of radio frequencios are required in the overcrowded ether, ono for the visual and another for the sound signals. In Television for September A. P. Peck describes a new system of broadcasting developed by the Columbia Broadcasting Company of New York which uses only one wave for both sight and sound signals and thus makes a smaller demand on the available channels in the ethor. A low-powered $45 \mathrm{kc}$. (kilocycle) oscillator is used in the first instance for the sound signals, the wave being modulated by the sound programme coming from the telovision studio. The sound modulated current includes frequencies up to $5 \mathrm{kc}$. on each side of the carrier wave. The wave with the television signals occupies the band on the frequency spectrum ranging from 2750 to $2850 \mathrm{kc}$. The sound signal is actually radiatod on two sub-carrier waves with frequencies of 2755 and 2845 respectively. With this arrangement the Columbia engineers have got satisfactory results. Not only does the method save space in the ether but it also saves equipment at each end. It is a great advantage to the average 'looker in' to have a receiver for both sight and sound which is compact, not easily damaged and simplo to operate.

\section{Revised Standard Frequency Radio Transmissions}

The modern extensive use of radio communication of all types demands for its success that each trans. mitting station shall keep very exactly to its allotted wave-length or frequency, so that interference with transmissions on neighbouring wave-lengths may be reduced to a minimum. At the present time the majority of commercial radio transmitting stations on land, including those employed for broadcasting purposes, use in their installation a source of oscillations the frequency of which is accurately controlled by means of a tuning fork or piezo-electric crystal. In order that the administrations to which these stations belong may be able to measure and adjust their wave-lengths very accurately, it is necessary that their controlling apparatus may be frequently checked against some national or international standard. It was to meet this need that on behalf of the Radio Research Board of the Department of Scientific and Industrial Research, waves of accurately known frequency have been transmitted for some years past from the wireless station at the National Physical Laboratory for checking the calibration of wavemeters and other apparatus.

THE programme of transmissions has recently been revised and the main standard now employed consists of a single frequency of 1,000 cycles a second. This frequency is derived from an installation which is maintained in continuous operation, day and night, at the National Physical Laboratory and serves as the national standard of Great Britain. This low frequency standard is emitted in the form of a modulation on a carrier wave the nominal frequency of which is $360 \mathrm{kc} . / \mathrm{s}$. (wave-length $830 \mathrm{~m}$.). A rogular monthly programme of such transmissions is now maintained by the National Physical Laboratory to enable all those desirous of doing so, to receive the transmission and to make a comparison between their own frequency standard and that of the Laboratory. In addition, a second quarterly programme of standard frequency transmissions consisting of a controlled carrier wave of frequency $1785 \mathrm{kc} . / \mathrm{s}$. , is still maintained by the Laboratory, largely for the benefit of amatour experimenters. Those interestod in this work can obtain a copy of the programmos of transmissions on application to the Secrotary, Department of Scientific and Industrial Research, 16 Old Queen Street, Westminster, London, S.W 1.

\section{Pharmacy and Recent Advances in Science}

TrE opportunities which the present rapid advances in science offer to the student formed the text of the address delivered by Dr. C. W. Kimmins at the opening of the School of Pharmacy of the Pharmaceutical Society of Great Britain on Oct. 5. For the scientific research worker there are all sorts of important problems awaiting solution. A student of organic chemistry frequently encounters puzzles such as this: a substance is known as a natural product of great medicinal value; the chomist works upon it and finds that a substance can be produced synthetically apparently exactly similar, yet the physiological properties may diffor in a marked degree. Many of these problems of the different action of synthetic and natural substances have been solved, but delightful fields for research remain. Evon in a limited field, to have extended tho bounds of human knowledge must over be a source of intense gratification to the worker. To take another example, in physical analysis, scientific workers at ono time concentrated exclusively on the elements of the visual spectrum; but of late years a great transformation has taken place. Men of science are concentrating on the larger wave-lengths on one side and the smaller wave-lengths on the other, with the relative neglect of the intermediate wavelengths. When the ultra-violet part is successfully

No. 3285 , Vol. 130] 